\title{
The Public Space Quality Of Lebih Beach Gianyar: Review Of Social And Economic Function
}

\author{
Kualtas Ruang Publik Pantai Lebih Gianyar tinjauan \\ Fungsi Sosial Dan Ekonomi
}

\author{
Ni Putu Diah Agustin Permanasuri ${ }^{(1)}$ \\ 1), Pendidikan Teknik Bangunan, Fakultas Keguruan dan Ilmu Pendidikan Universitas Palangka Raya \\ Kampus UPR Tunjung Nyaho J. H. Timang, 73111A \\ e-mail: diahpermanasuri@fkip.upr.ac.id
}

\begin{abstract}
The function of a public space one of them is a place for interaction, social activity, and needs fulfillment for economy and recreation. The provision of public space is mandatory on the level of city or town. The public space quality based on abrasion impact can be seen from physical and non-physical aspect. Physical aspects include region facilities, public space conditions, and design. Non-physical aspects include responsive element, democratic, to offer meaning and accessibility. Lebih Beach as public space was located in Gianyar Regency, has unique attractions to the community with several activities such as social activities, economic, family entertainment, culinary adventures, etc. Lebih Beach currently experienced lots of changes such as physical change due to abrasion, lesser beachfront. These conditions caused the quality change of the beach, and this research is to describe how the Lebih beach quality on the social and economic aspects as the dominant activities in the area. This research is a qualitative descriptive research, data obtained by direct interview with visitors. On the social function, the quality obtained is from democratic aspect and meaningful, while from economic function, democratic aspect was obtained, meaningful and region quality.
\end{abstract}

Key words: public space quality, social function, economic function, Lebih Beach

\begin{abstract}
ABSTRAK
Fungsi sebuah ruang publik diantaranya sebagai tempat berinteraksi, melakukan aktivitas sosial, dan pemenuhan kebutuhan akan perekonomian ataupun rekreasi. Ketersediaan ruang publik wajib ada baik pada tingkat kota maupun skala yang lebih kecil. Kualitas ruang publik berdasarkan dampak abrasi diantaranya dapat dilihat dari aspek fisik dan non fisik. Aspek fisik meliputi fasilitas kawasan, kondisi ruang publik, dan desain. Aspek non fisik meliputi unsur responsif, demokratis, memberi arti dan aksessibilitas. Pantai Lebih sebagai sebuah ruang publik berlokasi di Kabupaten Gianyar,memiliki daya tarik tersendiri bagi masyarakat, terdapat berbagai aktifitas didalamnya, antara lain aktifitas sosial, ekonomi, hiburan keluarga, wisata kuliner dan lain lain. Pantai Lebih saat ini mengalami perubahan yang cukup banyak, diantaranya perubahan fisik pantai akibat abrasi, terjadi pengurangan jarak daratan dengan bibir pantai. Kondisi ini menyebabkan terjadinya perubahan kualitas pantai itu sendiri, dan pada penelitian ini menguraikan bagaimana kualitas pantai Lebih pada aspek sosial dan ekonomi, karena aktifitas ini yang dominan terjadi di tempat tersebut. Penelitian ini merupakan penelitian deskriptif kualitatif, data diperoleh dengan wawancara secara langsung dengan masyarakat pengunjung. Pada fungsi sosial, didapatkan kualitas yang diperoleh adalah dari aspek demokratis dan meaningful, sedangkan dari fungsi ekonomi, didapatkan aspek demokratis, meaningful dan kualitas kawasan.
\end{abstract}

Kata kata kunci : Kualitas ruang publik, Fungsi sosial, Fungsi ekonomi, Pantai Lebih

\section{PENDAHULUAN}

Ruang publik yang dimaksud dalam tata guna lahan atau pemanfaatan ruang wilayah atau area perkotaan adalah ruang terbuka (open space) yang dapat diakses atau dimanfaatkan oleh warga kota secara cuma-cuma sebagai bentuk pelayanan publik dari pemerintah kota yang bersangkutan demi keberlangsungan beberapa aktivitas sosial (rekreasi, kebersihan, keindahan, keamanan dan kesehatan) seluruhnya. Wujud dari ruang terbuka adalah berupa lahan tanpa atau dengan sedikit bangunan atau dengan jarak bangunan yang saling berjauhan; ruang terbuka ini dapat berupa pertamanan, tempat olah raga, tempat bermain anak-anak dan lain sebagainya (Departemen Pekerjaan Umum, 1992).

Fungsi sebuah ruang publik diantaranya sebagai tempat berinteraksi, melakukan aktivitas sosial, dan pemenuhan kebutuhan akan rekreasi. Ketersediaan 
ruang publik wajib ada baik pada tingkat kota maupun skala yang lebih kecil. Ruang publik (public space) sebagai sebuah obyek fisik secara sederhana dapat didefinisikan sebagai ruang maupun bentuk yang secara spasial dapat dimanfaatkan untuk mewadahi aktivitas bersama atau dapat dimanfaatkan oleh bersama dalam suatu kegiatan. Dengan adanya ruang publik, seluruh lapisan masyarakat dapat memiliki ruang untuk bersantai dan mendapatkan hiburan murah meriah, sehingga keberadaan ruang publik sebenarnya dapat menjadi ukuran tingkat stres masyarakat kota besar (Darmawan, 2003).

Sebagai salah satu ruang publik, kawasan pantai memiliki berbagai keunikan yang mampu menjadi daya tarik bagi masyarakat. Keindahan pantai dengan ombaknya, panorama matahari terbit dan tenggelam, yang menakjubkan dan tentunya akan mengundang decak kagum siapapun yang melihatnya. Selain sebagai kawasan perlindungan, pantai juga memegang peranan penting bagi masyarakat disekiranya, yakni digunakan sebagai tempat mata pencaharian mereka, baik sebagai nelayan, maupun sebagai petani garam dan rumput laut.

Pantai Lebih, merupakan pantai yang terletak di Desa Lebih Kabupaten Gianyar. Sebagai salah satu dari sebuah ruang publik, keberadaan pantai tersebut memiliki daya tarik tersendiri. Selain sebagai destinasi rekreasi, juga menyuguhkan tujuan destinasi kuliner ikan laut, serta destinasi wisata dan olahraga. Banyaknya nelayan yang menyandarkan perahunya serta tempat menyimpan peralatan menangkap ikan juga dapat kita temui, pada sisi tepi pantai. Seiring berjalannya waktu, Pantai Lebih telah mengalami beberapa perubahan, diantaranya perubahan fisik pantai, dimana garis pantai semakin mendekat ke daratan. Perubahan tersebut salah satunya disebabkan oleh adanya abrasi pantai. Saat ini, pantai Lebih memiliki garis pantai mencapai sekitar $3 \mathrm{~km}$ (Google map, 2019), kemudian jarak dari daratan ke bibir pantai mencapai 125 m (Suartika dkk, 2019). Dampak yang terjadi adalah terjadinya pengurangan kualitas pantai Lebih untuk dimanfaatkan sebagai suatu area ruang publik. Penelitian ini akan membahas bagaimana kualitas pantai Lebih sebagai suatu ruang publik ditinjau dari aspek sosial dan ekonomi.

\section{Tinjauan Pustaka \\ Ruang Publik}

Ruang publik menurut Stephen Carr, dkk (1992) merupakan suatu ruang milik bersama, untuk melakukan aktivitas baik itu aktivitas fungsional maupun ritual dalam suatu ikatan komunitas, dalam kehidupan sehari-hari maupun dalam perayaan berkala yang telah ditetapkan sebagai sesuatu yang terbuka, tempat untuk melakukan aktivitas pribadi dan kelompok. Ruang publik merupakan wadah aktivitas sosial yang melayani dan dapat mempengaruhi kehidupan masyarakat kota. Ruang terbuka juga merupakan wadah dari kegiatan fungsional maupun aktivitas ritual yang mempertemukan sekelompok masyarakat dalam rutinitas normal kehidupan seharihari maupun dalam kegiatan periodik (Carr,1992).

Ruang publik merupakan suatu elemen vital dalam sebuah ruang kota karena keberadaannya di kawasan yang berintensitas kegiatan tinggi. Sebagai lahan yang tidak terbangun, ruang terbuka biasanya berada di lokasi strategis dan banyak dilalui orang (Nazarudin, 1994).

\section{Kualitas Ruang Publik}

Tolak ukur penentu berkualitasnya suatu ruang publik ialah dengan memperhatikan tatanan aktivitas pengguna ruang tersebut, dan bagaimana hubungan aktivitas tersebut dengan elemen-elemen pembentuk tatanan fisik kawasan (Haryanti, 2008). Makna suatu tempat tidak hanya terbentuk oleh tatanan fisik semata, namun juga oleh tatanan fungsi yang terjadi dan bagaimana terjadi hubungan diantara keduanya. (Prihastoto, 2003). Pengertian ruang publik berkualitas mencakup juga makna dari keberadaan ruang publik tersebut dalam koteks yang berkelanjutan yaitu memenuhi kelayakan terhadap kriteria kualitas fungsional, kualitas visual, dan lingkungan (fisik dan non fisik).

Indikator yang dapat digunakan untuk mengukur kualitas ruang publik secara non fisik antara lain responsif, democratic, meaningful dan accessible (Carr, 1992). Ruang publik harus bersifat responsif (responsif spaces), yang menunjukkan bahwa ruang publik harus mampu melayani kebutuhan dan keinginan masyarakat penggunanya. Kriteria ini terbagi atas beberapa kriteria detail, yaitu bahwa ruang publik harus dapat memberikan kenyamanan (comfortable), relaksasi, pertemuan aktif, serta inspiratif. Bersifat demokratis (democratic spaces) yang menunjukkan bahwa ruang publik harus dapat melindungi hak individu dan kelompok masyarakat penggunanya. Ruang publik harus dapat memberikan arti (meaningful spaces) kepada penggunanya yang menunjukkan bahwa ruang publik harus dapat menciptakan kenangan dan arti tersendiri bagi pengguna. Kesan arti pada ruang publik sangat penting karena sebagai bagian image dari ruang publik itu sendiri. Ruang publik harus mudah dikunjungi (accessible spaces) yang menunjukkan bahwa ruang publik tersebut mudah dan aman dicapai masyarakat yang akan menggunakannya.

\section{Peran Ruang Publik}

Suatu ruang publik pada dasarnya memiliki beberapa fungsi dan peranan penting bagi masyarakat diantaranya dalam fungsi ekonomi dan fungsi sosial (Carmona, dkk, 2008).

\section{Fungsi Ekonomi}


Fungsi dan peranan ruang publik secara ekonomi ialah memberi pengaruh yang positif pada nilai properti, hal ini dapat dijelaskan karena dengan terjadinya aktivitas ekonomi pada ruang publik akan berdampak pada peningkatan aktivitas pada sektor properti, aktifitas ekonomi yang terjadi antara lain aktifitas jual beli antara pengunjung dan pedagang, tentunya dengan semakin ramainya aktifitas disuatu ruang publik berbanding lurus dengan peningkatan nilai jual suatu properti di kawasan tersebut, misalnya pembangunan restoran, warung makan, minimarket, dan lain lain. Peranan yang lain adalah meningkatkan performa ekonomi regional, hal ini dapat dijelaskan bahwa dengan tersedianya ruang publik, aktifitas warga dan wisatawan akan terpusat pada ruang publik tersebut, aktifitas perdagangan dan industri akan terpacu untuk memperkenalkan produk mereka untuk diperdagangkan, misalnya produk home industri seperti makanan dan minuman ringan, kerajinan tangan, dan produk lokal lainnya.

\section{Fungsi Sosial}

Ruang publik disebutkan juga memiliki peranan pada fungsi sosial dan budaya, kondisi ini berkaitan dengan fakta bahwa pada suatu kawasan ruang publik akan berkumpul sekelompok orang yang berasal dari latar belakang berbeda dan dengan kebutuhan yang berbeda pula, tentunya akan terjadi interaksi diantara sekelompok orang ini dalam berbagai hal, seperti hanya sekedar ngobrol, berbincang atau berdiskusi, pertemuan keluarga, ruang publik harus menyediakan kawasan yang aman nyaman bagi interaksi sosial tersebut, dan tersedianya ruang bagi warga melakukan kegiatan olahraga, atau hanya sekedar melepas lelah dengan duduk bersantai di kawasan tersebut. Kegiatan budaya pun bisa terjadi di suatu kawasan ruang publik, seperti di kawasan pesisir pantai di Bali, yang mempergunakan kawasan terbuka ruang publik untuk kegiatan Melasti atau pembersihan di pantai, dan tentunya kegiatan ini harus diakomodir oleh pemangku kepentingan setempat untuk menyediakan ruang publik yang aman dan nyaman bagi berlangsungnya kegiatan tersebut, kemudian tersedianya tenaga keamanan yang memadai sehingga pengunjung merasa aman saat beraktifitas di tempat tersebut.

\section{Metode}

Metode yang akan digunakan meliputi beberapa tahapan, antara lain

1. Pengumpulan data

- Wawancara: Informan yang diwawancarai berasal dari instansi perangkat desa yang dianggap memiliki kompetensi dalam bidang terkait penelitian, diantaranya Kepala Desa, Bendesa Adat, Kelian Desa, dan tokoh masyarakat Desa Lebih. Selain itu wawancara juga dilakukan terhadap para pengunjung Pantai Lebih, pelaku aktivitas yang terjadi di BALANGA: Jurnal Pendidikan Teknologi dan Kejuruan
Pantai Lebih, dan masyarakat sekitar yang memanfaatkan ruang pada Pantai Lebih Gianyar

- Observasi Lapangan: data dikumpulkan dengan pengamatan langsung ke pantai Lebih, dan juga menggunakan alat penunjang berupa perekam dan kamera

2. Pengolahan data

Hasil wawancara dianalisa menggunakan landasan teori yang ada, untuk kemudian diolah dan mendapatkan suatu kesimpulan.

\section{Hasil dan Pembahasan}

Indikator yang menentukan berkualitasnya sebuah ruang publik, dapat ditinjau dari dua aspek yakni aspek fisik dan aspek non fisik. Aspek fisik meliputi fasilitas kawasan, desain, dan kondisi. Kemudian aspek non fisik diantaranya responsif, demokratis, memberi arti (meaningful) dan aksessibilitas (Carr, 1992).

Fungsi sosial yang berlangsung di pantai Lebih diantaranya adalah kegiatan olahraga di jogging track, kegiatan rekreasi berupa memancing, bersantai dan duduk duduk disekitar pesisir pantai, kegiatan keagamaan berupa melasti, nangluk merana, nganyud, dan melukat/pebersihan.

Berdasarkan hasil dari wawancara dengan para responden, dan dikaitkan dengan teori, sebuah ruang publik hendaknya mampu menampung berbagai kegiatan/aktivitas yang terjadi pada ruang publik tersebut, dalam hal pewadahan dari fungsi sosial ruang publik di pantai Lebih ini, aspek dari kualitas ruang publik yang cenderung memenuhi adalah demokratis dan mampu memberi arti (meaningful). Aspek demokratis ialah ruang publik mampu melindungi hak individu/ kelompok pengguna ruang publik, setiap pengguna akan mendapatkan hak yang sama dalam penggunannya. Memberi arti ialah ruang publik mampu memberikan kenangan tersendiri, sejarah, dan tradisi budaya.

Fungsi ekonomi yang berlangsung di pantai lebih diantaranya adalah aktifitas perdagangan olahan ikan berupa warung makan / kuliner dan aktifitas mata pencaharian nelayan. Dalam hal pewadahan fungsi ekonomi ruang publik di pantai Lebih, aspek kualitas yang cenderung memenuhi adalah aspek responsif, yaitu mampu memenuhi kebutuhan masyarakat yang berkunjung ke pantai Lebih, utamanya aktifitas kuliner, berikutnya aspek demokratis, yaitu fungsi ekonomi di pantai Lebih tidak membedakan pengunjung yang datang, dan melindungi hak setiap individu, aspek lain yang memenuhi aspek kualitas adalah terpenuhinya fasilitas kawasan, yaitu warung makan kuliner yang ada sudah memiliki tempat yang layak, disertai fasilitas toilet yang memadai, kawasan yang tertata baik dan terpisah dari risiko ancaman ombak besar, sehingga membuat pengunjung yang datang untuk bersantap merasa nyaman. 


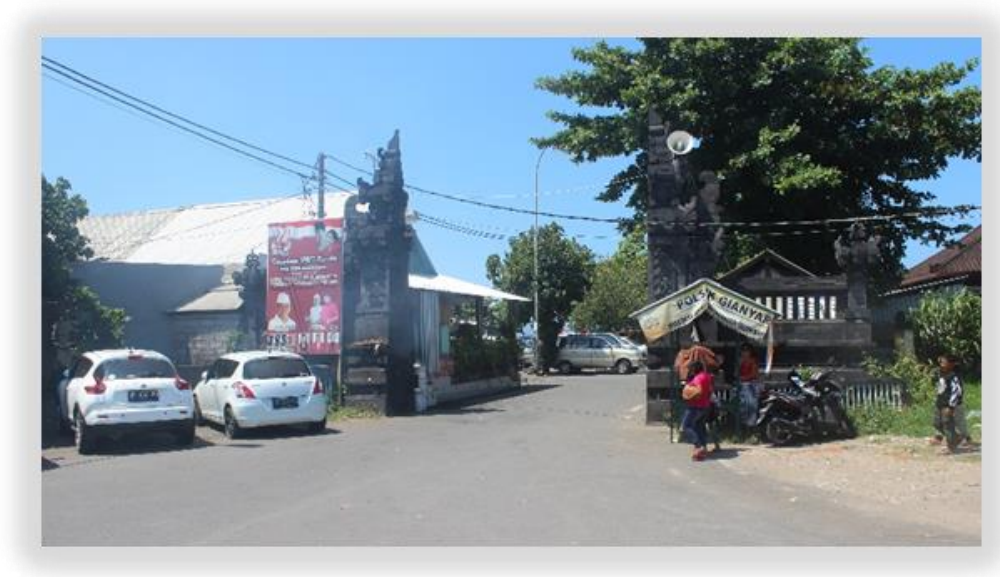

Gambar 1. Pintu Masuk menuju Pantai Lebih Dokumentasi Pribadi, 2019

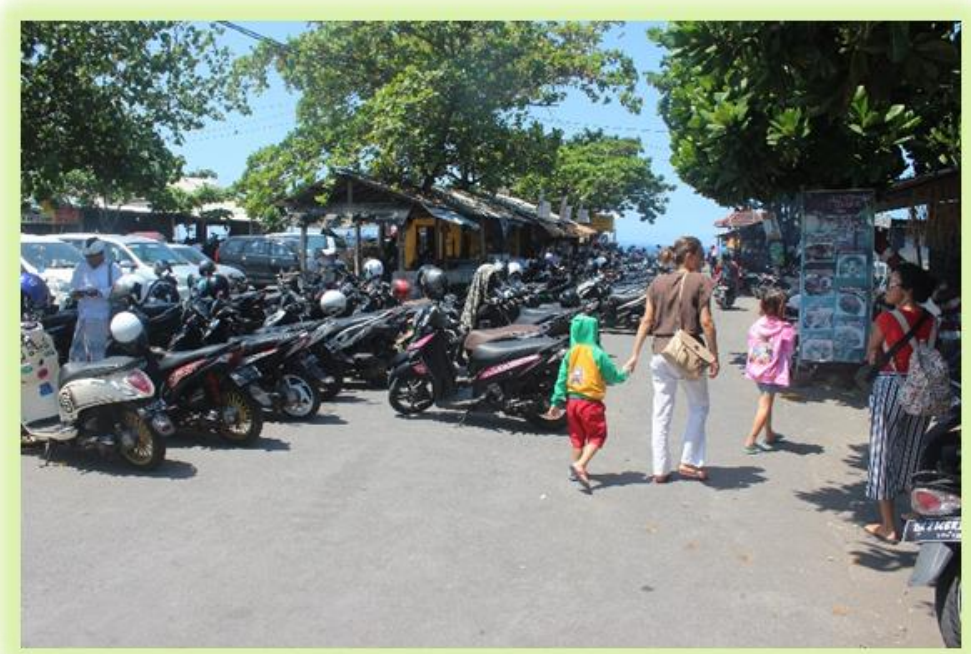

Gambar 2. Areal Parkir

Dokumentasi Pribadi, 2019

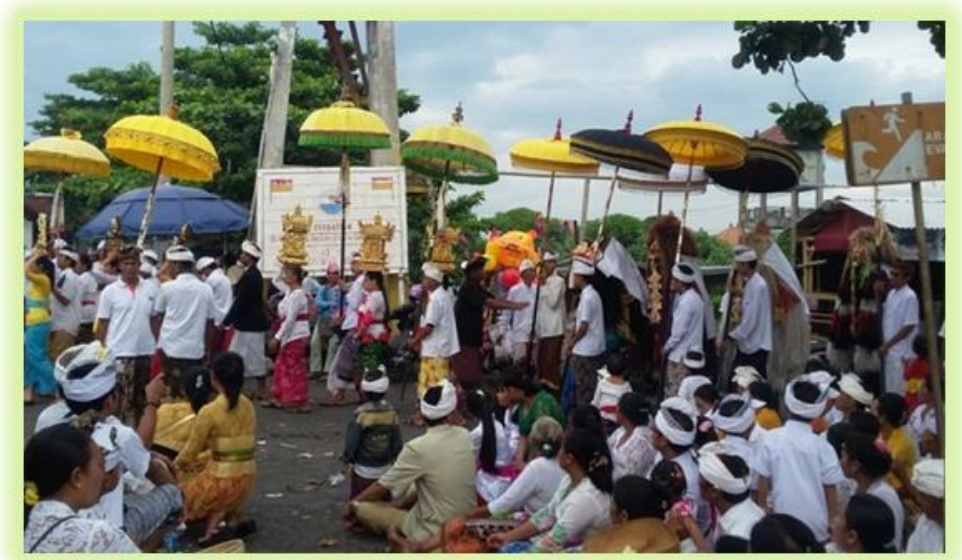

Gambar 3. Aktifitas Keagamaan

Dokumentasi Pribadi, 2019 


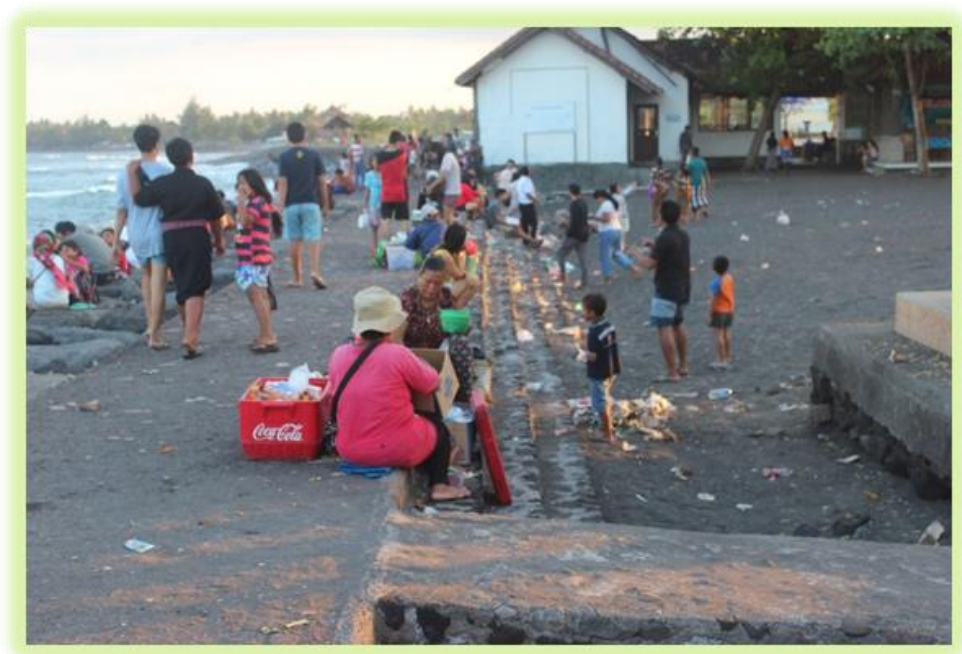

Gambar 4. Aktifitas Rekreasi

Dokumentasi Pribadi, 2019

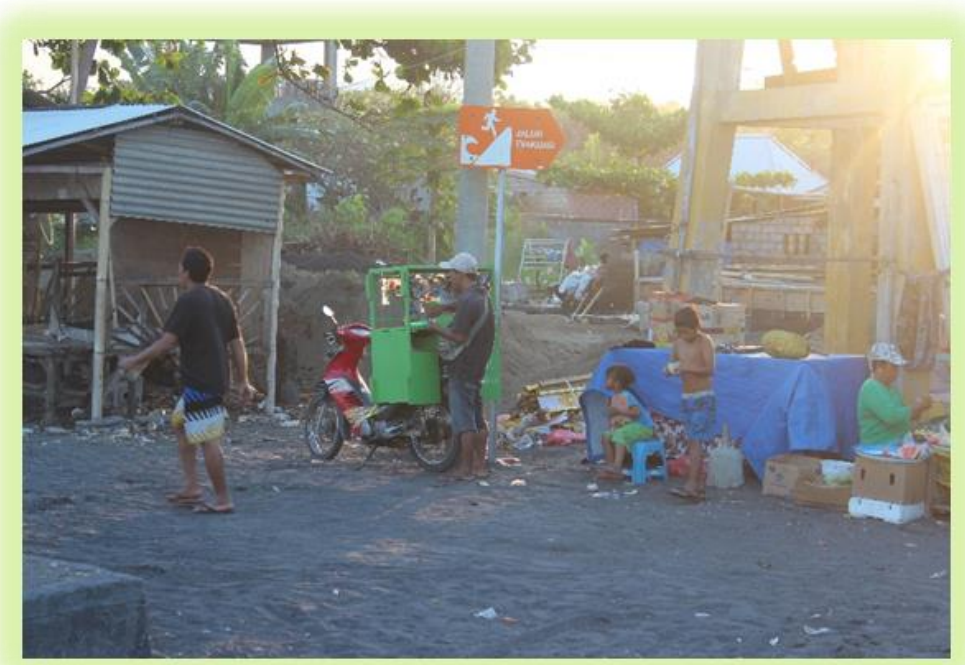

Gambar 5. Aktifitas Rekreasi

Dokumentasi Pribadi, 2019

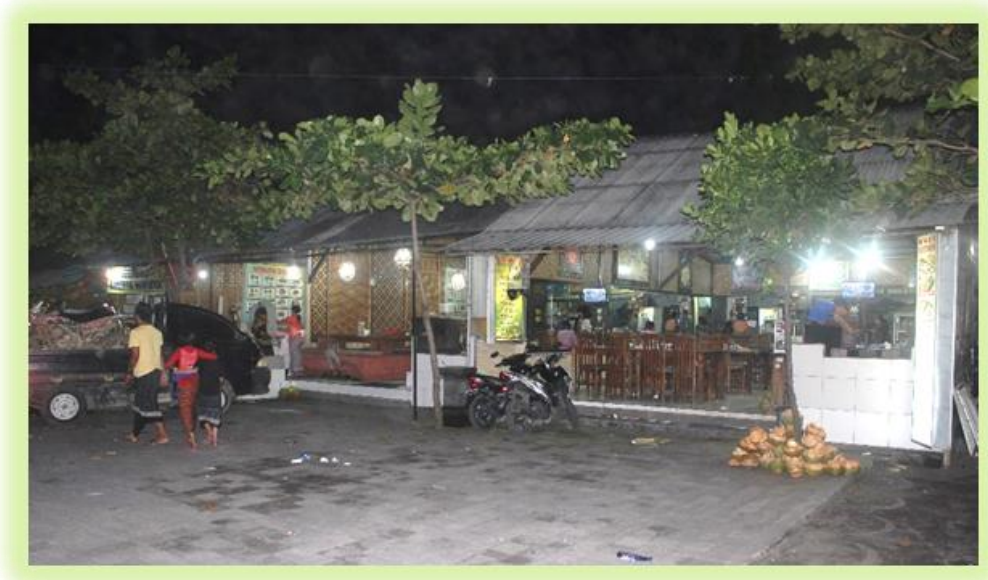

Gambar 6. Warung makan (kuliner)

Dokumentasi Pribadi, 2019 


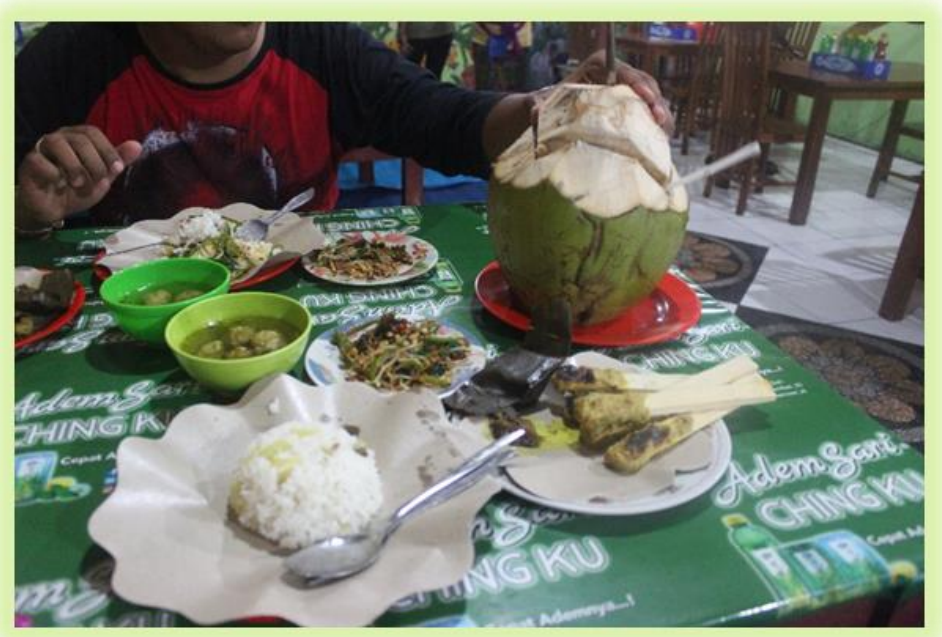

Gambar 7. Menu olahan ikan

Dokumentasi Pribadi, 2019

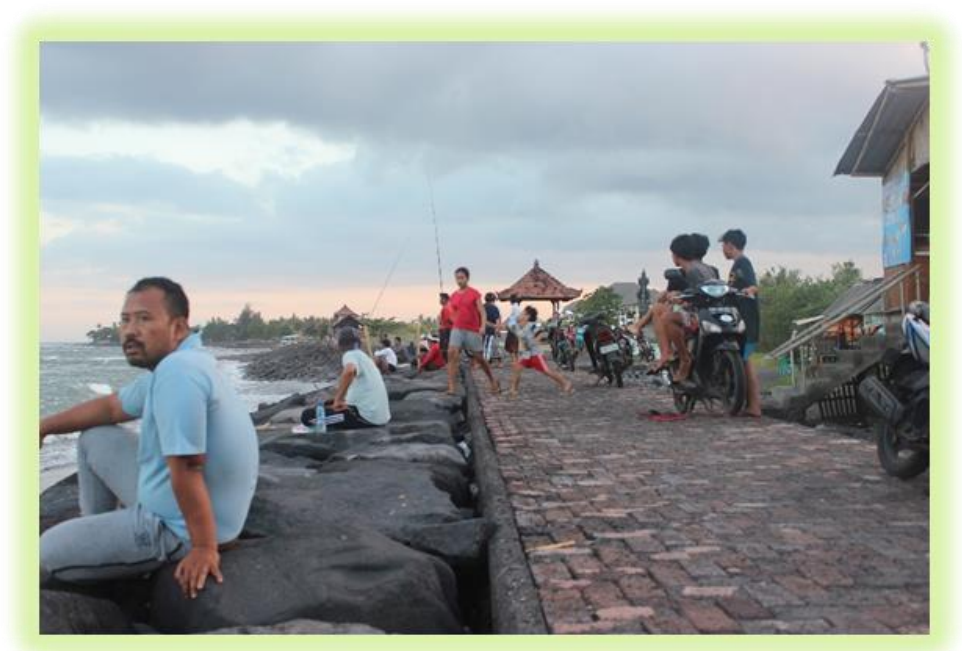

Gambar 8. Aktifitas Rekreasi

Dokumentasi Pribadi, 2019

\section{Kesimpulan}

Ruang publik Pantai Lebih sebagai fungsi ekonomi diantaranya ruang publik tersebut dimanfaatkan sebagai kegiatan perdagangan yaitu warung kuliner, pengerajin batu sikat, dan mata pencaharian nelayan. Kualitas dari sebuah ruang publik diantaranya memenuhi unsur responsif, demokratis, memberi arti (meaningful), dan aksesibilitas (accesible). Kualitas ruang publik terhadap fungsi sosial yakni aktifitas yang berkaitan diantaranya olahraga, rekreasi dan keagamaan, dari hasil observasi dan wawancara, para pengguna ruang publik tidak memperoleh kenyamanan dalam melakukan aktivitas sosial, disebabkan adanya pengamanan pantai (revetment) dan tumpang tindih kegiatan yang terjadi, pada area ruang publik. Kualitas dari fungsi ekonomi, dimana kegiatan ekonomi perdagangan oleh para pengguna kegiatan tersebut merasakan kenyamanan dalam menggunakan ruang publik, berbeda hal nya dengan kegiatan ekonomi yang dilakukan oleh pihak nelayan, nelayan dalam hal ini tidak merasakan kenyamanan dalam menggunakan ruang publik dikarenakan pengamanan pantai yang ada menghambat aktivitas nelayan dalam menaikkan ataupun menurunkan perahu untuk berlayar mencari ikan.

\section{Saran}

Perlu dilakukan penataan terhadap ruang publik Pantai Lebih dengan memberikan batasan ruang yang jelas agar tidak terjadi tumpang tindih kepentingan dalam melakukan aktifitas di ruang publik Pantai Lebih. 


\section{Daftar Pustaka}

BALI R T R W P 2009 Peraturan Daerah Provinsi Bali Nomor 16 Tahun 2009 Tentang Rencana Tata Ruang Wil. Provinsi Bali Tahun 2029

Bappeda 2012 Rencana Tata Ruang Wilayah Kabupaten Gianyar Tahun 2012-2032

Carr S, Stephen C, Francis M, Rivlin L G and Stone A M 1992 Public space (Cambridge University Press)

Carmona, Matthew et all. 2003. Public Place Urban Space: The Dimention Of Urban Design. New York: Elsevier.

Carmona, et al. 2008. Public Space: The Management Dimension. Routledge, Taylor\&Francis group. New York, USA.

Darmawan E 2003 Teori dan Kajian Ruang Publik Kota Semarang Badan Penerbit Univ. Diponegoro

Darmawan, Edy. 2009. Ruang Publik Dalam Arsitektur Kota. Semarang: Badan Penerbit Universitas Diponegoro.

Haryanti, D.T. 2008. "Kajian Pola Pemanfaatan Ruang Terbuka Publik Kawasan Bundaran Simpang Lima Semarang" (tesis). Semarang: Universitas Diponegoro.
Permanasuri NPD, 2019. "Pemanfaatan Ruang Publik Akibat Abrasi di Pantai Lebih Gianyar". Tesis Tidak Diterbitkan. Program Pascasarjana Magister Arsitektur Universitas Udayana.

Ruang D J P 2007 Undang-Undang Republik Indonesia Nomor 26 Tahun 2007 tentang Penataan Ruang Dep. PU. Jakarta

Sukmadinata N S 2009 Metode Penelitian Pendidikan (Bandung: PT. Remaja Rosdakarya)

Sunaryo, R.G. 2009. "Perubahan Setting Ruang dan Pola aktivitas Publik di Ruang Terbuka Kampus UGM". Seminar Nasional Riset Arsitektur dan Perencanaan (SERAP)1 HUMANISME, ARSITEKTUR dan PERENCANAAN. Yogyakarta.

Suartika G A M 2015 Sand, sea and ceremony: conflict over the littoral public realm in Sanur, Bali ProcediaSocial Behav. Sci. 179 128-40

Triatmodjo B 1999 Teknik pantai Beta Offset, Yogyakarta 397

Wardhono F and Hesti N 2012 Pembangunan Kota Berkelanjutan Present. sebagai bagian dari Lap. akhir berjudul "Kajian Upaya Perwujudan Kota Jakarta yang Berkelanjutan 